\begin{tabular}{ll}
\hline \hline MINING AND METALLURGY INSTITUTE BOR & ISSN: 2334-8836 (Štampano izdanje) \\
UDK: 622 & ISSN: 2406-1395 (Online) \\
\hline \hline
\end{tabular}

\author{
Nemanja Matić, Boris Siljković**, Marko Savić***
}

\title{
POTENTIALS OF TRADITIONAL CASH METAL COINS VERSUS DIGITAL CONTACTLESS PAYMENT IN THE TIME OF CORONAVIRUS PANDEMIC
}

\begin{abstract}
This paper addresses the challenges associated to the strength of potential for payment with traditional metal cash and paper money versus a non-cash method of payment in the era of the COVID 19 pandemic in the world and our country. The pandemic served to accelerate the contactless method of payment, because payment without contact is now not only a convenience, but a necessity. Before the pandemic in Europe, cash accounted for close to half of the payments, and in just a few weeks of the COVID 19 pandemic, it fell by 10 percent. Concepts that have so far preferred cash were definitely compromised during the pandemic crisis, and the pandemic is actually the strongest marketing of digital contactless payment methods so far, through the dominant contactless style of money exchange in the world and Europe, as shown in the paper we have today.

Some research studies described in the paper in form of the health adventages of mobile wallet payments, as opposed to the proven health-threatening cash and coin-based cash payment model, indicate that the end of the cash era is approaching, being primarily accelerated by the health risk of COVID 19 infection. Particularly interesting is the live study conducted in the area of the northern Kosovo and Metohija, presented in a form of a set of financial services offered by the Postal Savings Bank of the Kosovska Mitrovica branch office, and relation between the contactless and cash payment model, before and after the COVID 19 pandemic. Naturally, all of this is accompanied by significantly limited knowledge related to SARS Cov 2, better known as the current COVID 19 pandemic.
\end{abstract}

Keywords: paper money, metal money, cash, contactless payment, COVID 19, pandemic

\section{INTRODUCTION}

The coronavirus pandemic of 2020 promoted digital mobile, network and contactless payment, which means that there are few arguments against application of this model in the post-pandemic period. E-banking involves delivery of banking products and services through the electronic channels that had been previously done through telephone transactions and automatic teller machines (ATMs). Later, with the Internet application, which was considered as the fastest and best

channel for delivery of most banking transactions, the job was made easier both for banks and customers. Khalek and Bakri [1] Telephone, Internet and mobile phone have become the main channels of digital banking services making them important for the survival of banks, due to their advantages and practicalities, anytime and anywhere. Sundarraj and $\mathrm{Wu}$, 2005; [2], Daniel, 1999; [3], Mols, 2001. [4] During and after the corona virus pandemic, the banking world, along with the

\footnotetext{
*Delikos DOO Sopot, maticnemanja6@gmail.com

** Academy of Applied Studies, Department Peć-Leposavić, boris_siljkovic@yahoo.com, savic22@yahoo.com
} 


\section{HEALTH POTENTIAL OF DIGITAL AND CASH EXCHANGE OF MONEY IN THE AGE OF THE COVID PANDEMIC 19}

ecologically contactless payment everywhere in the world, should become absolute priority. This payment model will almost certainly be present for a long time even after the coronavirus pandemic. The coronavirus pandemic will definitely change everything that was once the norm of traditional banking financial services, especially the cash payment method and the digital payment method. Digital contactless banking enables the development of customer services, reducing the costs associated to face-to-face transactions with customers in branch offices. Dootson et al., 2016. [5]

The model of traditional banking is being tested during this coronavirus pandemic and it has been shown that the traditional cash payment model is currently outdated. The European Central Bank surveys conducted in June 2020 showed a sharp decline in the share of cash payments during the first lockdown of economies across Europe where consumers pay in cash, but much less than before the pandemic.

Knowledge and people who know how to apply that knowledge participate in the development of society nowadays. [23] This has primarily allowed the electronic contactless banking, which represents the application of the new/old technological solutions, and has made possible to the users to perform the money transactions from anywhere and at any time they want using the computer networks. Ilić et al., 2015 [6]
The time of pandemic has indicated that we have an adaptable so-called a coronavirus environmental bank that has an updated model of digital services including a health strategy of contactless payment methods. The BRIC countries, specifically the Government of India will perform all payments in the futuristic world using the contactless cards, mobile phone applications and other electronic means, while the banknotes and coins will be abolished. [7]

Contactless payment was already on the rise in the U.S.A, but the ongoing coronavirus pandemic has increased the number of Americans using a variety of non-contact payment methods.

In the US, more than $51 \%$ of people have opted to use so-called mobile wallets, such as the Apple Pay and other TapTo-Go credit cards. Consumers mainly use the contactless cards to buy necessities, namely: food: $85 \%$, pharmacy: $39 \%$, retail: $38 \%$ fast food restaurants (KSR), fast food: $36 \%$. [8].

Table 1 actually shows the reasons why the health benefits of digital payment in the COVID 19 pandemic era have prevailed over the traditional cash and paper money payments.

China, where coronavirus COVID 19 or Sars Cov 2 first appeared, and its Chinese National Health Commission have classified the new coronavirus as a class A infectious disease, requiring the strictest preventive and control measures, including mandatory patient quarantine and treatment of those who were in a close contact with them [19]. 
Table 1 Health potential of using the digital contactless payment versus use of metal and paper money

\begin{tabular}{|c|c|}
\hline Use of metal coins & $\begin{array}{l}\text { It is moderately contagious and depends on the } \\
\text { composition of the money alloy, its production is } \\
\text { more expensive, up to two times of nominal value, } \\
\text { and it is harder to protect against counterfeiting. }\end{array}$ \\
\hline Use of paper money & $\begin{array}{l}\text { Contagious for several days, cheaper to make than } \\
\text { coins and easier to protect against a counterfeiting } \\
\text { than coins. }\end{array}$ \\
\hline $\begin{array}{l}\text { Use of contactless card, Master and } \\
\text { Visa card. In the USA, cards of the } \\
\text { present and the future } \\
\text { (Visa Inc., Mastercard Inc., American } \\
\text { Express Co., PayPal Holdings Inc.) }\end{array}$ & $\begin{array}{l}\text { Less contagious if contactless, does not change the } \\
\text { owners and does not come into contact with sellers } \\
\text { and traders. A plastic card costs less than paper } \\
\text { money and coins, because it can be used longer - } \\
\text { commercial moment. Payment cards have eliminat- } \\
\text { ed the need to carry money while reducing the } \\
\text { chances of theft or loss of currency. }\end{array}$ \\
\hline $\begin{array}{l}\text { Mobile applications for payment } \mathrm{E} \\
\text { banking, Home banking and } \mathrm{M} \text { bank- } \\
\text { ing, so-called digital wallets }\end{array}$ & $\begin{array}{l}\text { The least contagious with the use of hygienic clean- } \\
\text { ing products for the phone. It requires a mobile } \\
\text { phone or computer and an Internet connection. }\end{array}$ \\
\hline Cardboard & The virus remains on it for 24 hours. [9] \\
\hline $\begin{array}{l}\text { Stainless steel (banknotes) and plastic } \\
\text { cards }\end{array}$ & $\begin{array}{l}\text { Research 1: Materials on which germs and viruses } \\
\text { can be minimum kept: Sars Cov } 1 \text { and SARS Cov } \\
2-5.6 \text { hours on stainless steel and } 6.8 \text { hours on } \\
\text { plastic. Although the extent of the virus has been } \\
\text { significantly reduced, this virus is more stable. } \\
\text { Research 2: Even after } 72 \text { hours, SARS Cov } 2 \\
\text { could be found on plastic and } 48 \text { hours on stainless } \\
\text { steel [10] }\end{array}$ \\
\hline $\begin{array}{l}\text { Solid surfaces and materials e.g. ATMs } \\
\text { and POS terminals }\end{array}$ & $\begin{array}{l}\text { Sars Cov } 2 \text { virus can stay alive for up to two days } \\
\text { [11] }\end{array}$ \\
\hline Copper alloy for money banknotes & $\begin{array}{l}\text { SARS-CoV } 2 \text { or Covid } 19 \text { virus remain present for } \\
4 \text { hours. It has been proved that copper-containing } \\
\text { surfaces show antiviral activity as opposed to pol- } \\
\text { ymer surfaces used to make paper banknotes, where } \\
\text { the virus could survive for several days. [12] Cop- } \\
\text { per deficiency, although rare, makes people more } \\
\text { susceptible to infection. [11] The continuously self- } \\
\text { sterilizing form of copper is } 99 \% \text { capable of deac- } \\
\text { tivating SARS-CoV-2 or COVID } 19 \text { in } 30 \text { seconds. } \\
\text { [12] }\end{array}$ \\
\hline Metal and glass & $\begin{array}{l}\text { Analysis of } 22 \text { studies reveals that the human coro- } \\
\text { naviruses such as the Severe Acute Respiratory } \\
\text { Syndrome (SARS), Middle East Respiratory Syn- } \\
\text { drome (MERS) or Endemic Human Coronaviruses } \\
\text { (HCoV) can persist on inanimate surfaces such as } \\
\text { metal, glass or plastic for up to } 9 \text { days. [13] }\end{array}$ \\
\hline
\end{tabular}




\section{PRIMATE OF DIGITAL MONEY \\ EXCHANGE AS THE MAIN STYLE IN THE AGE OF THE COVID 19 PANDEMIC IN THE WORLD WITH REFERENCE TO SERBIA}

If we use the research and online survey of Accenture NYCE: in 20 countries with 120 bank directors during the pandemic from July to August 2020 as shown in Figure 1 below, it can be seen that the biggest payment disruption was in the USA, followed by the UK, because the consumers have been opting for the new digital payment methods. The surveyed markets include: Australia, Brazil, Canada, China, Denmark, Finland, France, Germany, India, Italy, Japan, the Netherlands, Norway and Singapore. In China, for instance, the mobile wallets are rapidly taking precedence over cash payments $76 \%$ of transactions in 2019 come from mobile wallets, compared to $12 \%$ in 2014 . For several years now, the consumers in China have been accustomed to use the mobile applications and QR codes to pay in restaurants and stores. Even before the pandemic, China was the second in the global share of payments by mobile wa- llets and the second market with the fastest growth of payments in the world. In Germany, more than half of card payments in the year of the pandemic were contactless, compared to $35 \%$ before the economy was hit by the coronavirus crisis. Since June 2020 in the Netherlands, consumers have paid $20 \%$ in cash at their points of sale. This is significantly lower than in January and February 2020, when $30 \%$ of their purchases were paid for in cash, but more than immediately after the outbreak of COVID 19. In the Netherlands in April 2020, only $15 \%$ of purchases were paid for in cash. In October 2020, the consumers used the contactless payment methods for $67 \%$ of their purchases at points of sale, compared to only $50 \%$ at the beginning of the year. As it can be seen in Figure 1, the contactless payment in the Netherlands has increased to the detriment of cash payments, and in particular pin-code mobile payment QR telephone code payment. [22]

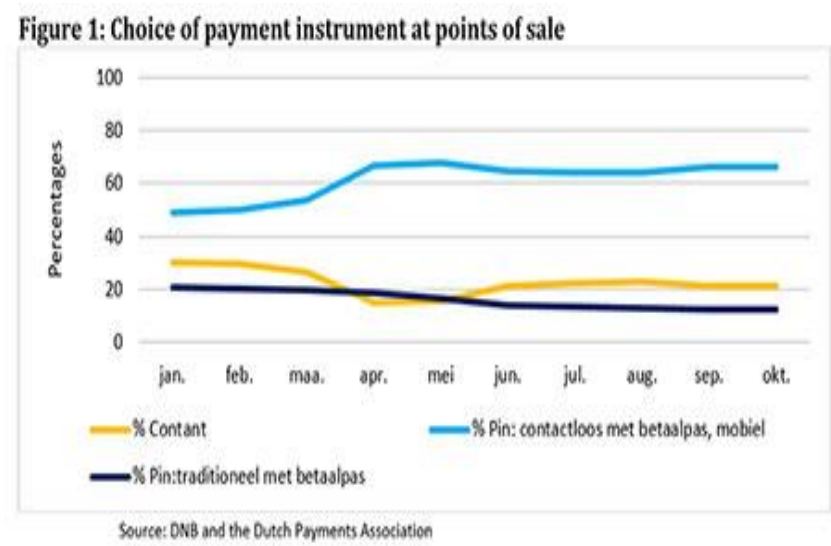

Figure 1 Choice of payment instruments in the Netherlands at points of sale [22] 
If we look in Figure 2 in the UK in a pandemic year, the "tap and pay" model makes up more than $40 \%$ of card payments. In mature markets - such as Western Europe, payments are mostly commodified - only gradual changes are expected to be seen through purchases. The greatest opportunity for contactless payment will be in markets such as Southeast Asia and Latin America, where a cash consumption dominated, and, in some regions, has even increased during the pandemic. The size of a circle in Figure 2 indicates the relative value of transactions in each country. [14] [22] [15]

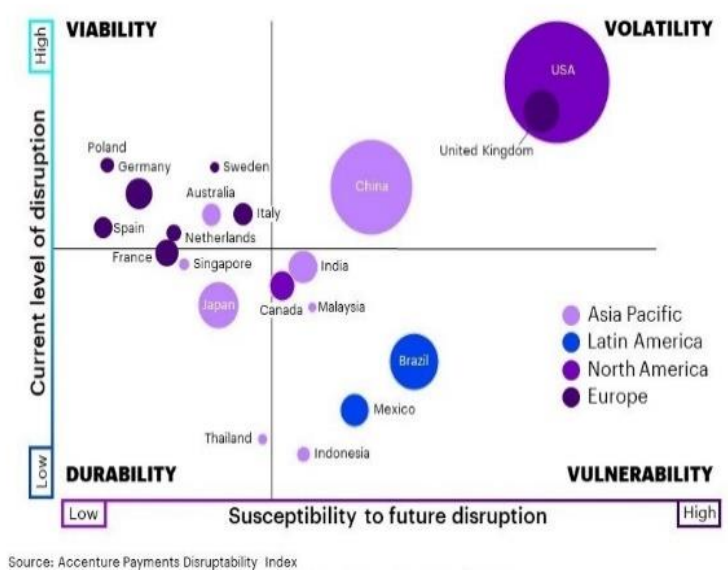

Figure 2 Increase of digital payments during the COVID 19 pandemic worldwide [14]

Almost all users of smartphone services will be in the Asia-Pacific region and mainly in China, which will make up the majority of the world's users of direct mobile payments. Mobile payments are also popular among the smartphone users in India, Denmark, Sweden and South Korea. The information in Figure 3 presents an overview of the global proximity payment environment through the mobile applications, including adoption trends in major markets and key players.

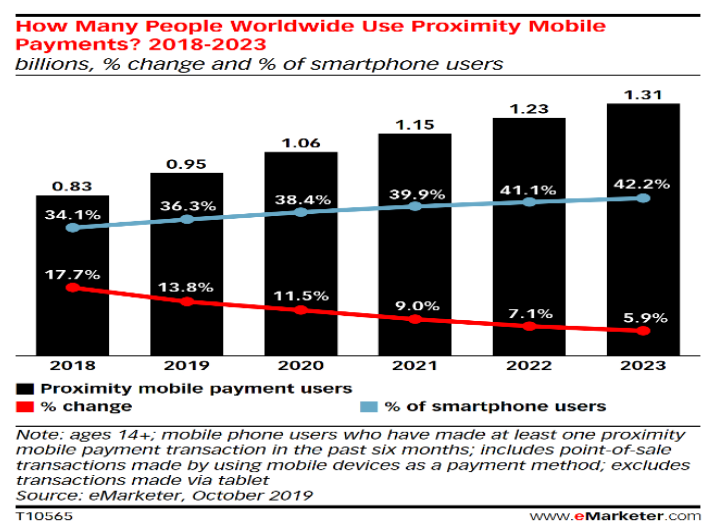

Figure 3 Predictions of payment services via mobile applications in the world 2018-2023 [16] 
A strong cash payment culture is giving way to the non-cash payment methods mainly due to the COVID 19 pandemic and in order to prevent the spread of coronavirus. For instance, in 2020, there will be 59.3 million mobile payment users in Western Europe, close to $18.7 \%$ more than in the previous year. Stable growth is expected until 2023 through the number of service users, when 70.6 million people in the region will have performed at least one proximity mobile payment transaction in the past six months. Sincerily, in numerical terms, the growth of people using mobile applications is predicted, and in percentage terms, there is a noticeable decline in users of contactless mobile payment services as we move away from the base pandemic 2019 in Western Europe, and Figure 4 directly proves it. [17]

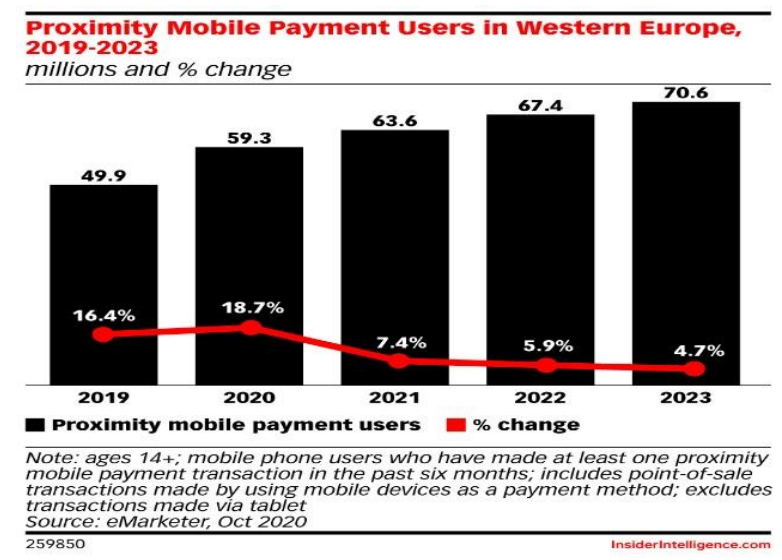

Figure 4 Riselfall in mobile phone payments 2019-2023 in the economies of Western Europe [17]

According to a research conducted by BuyShares.co.uk in June 2020, the global mobile wallet industry is worth $\$ 1.47$ trillion versus $\$ 405$ billion in 2017 . The number of people choosing mobile wallets to manage their payments should jump over $29.6 \%$ per year by the end of 2020 . The data reveals that China is the leading player in the mobile wallet industry, and is predicted to reach a value of $50 \%$ of the world's overall market value in 2020 . However, the statistics show that the United States, Great Britain and Brazil, as the leading markets for mobile wallets, are expected to grow in 2020. [18]

Serbia is in the early stages of ebanking growth because just over a third of the population is currently active or involved in e-m banking. We had introduced the mobile wallets in Serbia, and it was thought that everyone would immediately pay exclusively by phone. Will the COVID 19 pandemic change that, and indications show that it will continue in 2021, with long term consequences. However, the health progress is certain, but not visible enough for the time being, since the mass immunization just began in January 2021.

When it comes to the wider use of mobile wallets, it is still going slowly both in Serbia and the region, cash is still used a lot. What is being talked about and written about everywhere is reaching the ordinary people and wider population in the region and Serbia more slowly. 


\section{LIMITATION / DIVERSITY OF PAYMENT METHODS - CASE STUDY POSTAL SAVINGS BANK - KOSOVO MITROVICA}

Since the declaration of the state of emergency in Serbia and the proclamation of the COVID pandemic on March 19, 2020, the Postal Savings Bank in Serbia with its branch office in Kosovska Mitrovica has invited its clients to use the electronic banking services as much as possible, i.e., remote access to payment services and transactions. Here, for our needs, and in order to determine the factual situation in the area of the branch office of the Postal Savings Bank in Kosovska Mitrovica, we have made an analysis through an anonymous survey. For this purpose, we have made an overview of the use of contactless versus cash payment methods from the point of view of usersclients and service providers on the example of the Postal Savings Bank of Kosovska Mitrovica and its four municipalities through the branche office in which they operate: Kosovska Mitrovica, Zvecan. Zubin Potok and Leposavic.

At the very beginning of the research, we encountered a crucial limitation in form of impossibility of using electronic payment services in full capacity for the simple reason of unavailability, i.e., relatively small number of POS terminals in retail stores, restaurants, restaurants and other facilities. It is noteworthy that there is still a lack of culture of electronic payment amongst the population of the northern Kosovo and Metohija, although some progress in the use of electronic services is noticeable, especially after the declaration of the pandemic and the use of electronic payment methods.

Due to these facts, all types of electronic services, primarily payment cards and mobile applications offered by the Postal Savings Bank of the Kosovska Mitrovica branch office, have limited practical and application value. Therefore, the bank's client/consumer is prevented from using the so-called mobile wallet and electronic services in full capacity and is mostly oriented towards the cash method of payment and use of services in the territory of the northern Kosovo and Metohija. When it comes to the Posatal Saving Bank, it called on clients to use the electronic banking services as much as possible, i.e., remote access to payment and payment services in the conditions of the state of emergency in the country, declared to prevent spreading of the Covid-19 virus.

Due to these circumstances, we have focused on examining the provision of financial services of the Postal Savings Bank in the north of Kosovo and Metohija, which is registered as a service provider in Serbia, and this bank in Kosovska Mitrovica was officially opened on April 1, 2018 and operates in the payment system of Serbia.

The conducted survey was of an anonymous type, with 100 people of different ages from 25 to 65 and older participated, where both sexes were equally represented. Time period of the survey was March 2020 - August 2020. We received the greatest number of answers from the respondents of young age 35-44, and middle age 45-54. Significantly few participants were very young aged 18-25 and mature over 65-70.

Persons with the high school and faculty degree were equally represented in the answers. Very few people with primary school and high academic degree of master and doctor of science participated.

Based on the answers to the questions asked, it was confirmed that cash withdrawal is the dominant form of using the services of the Post Office in the north of Kosovo and Metohija, with most clients. The survey has shown that the younger population prefers contactless payment methods mainly through mobile applications, but it is insufficiently/very little used. It is noteworthy that all categories of the surveyed population agreed that the following types of electronic payment payments are popular from the health perspective: a). card, b). mobile appli- 
cation, followed by c). check and e) cash. True, it may be stated that the respondents of all ages did not have an aversion for the use of cash as a method of payment and withdrawal of cash during the current pandemic.

Due to these reasons related to the use of cash and the respondents' answers that there were no fears in terms of health security, a new study from the USA in 2020, which proves the opposite, is being analysed. In the appendix below, Table 2 has provided sufficient evidence that there is contamination with the COVID 19 virus (SARS Cov 2) and that paper for money printing may be less contagious with the Coronavirus (Covid 19) than banknotes. However, both this and previous studies have shown that coins and banknotes can be highly transmissible and pathogenic. (Evidence - Table 1). Mobile phones and computers may be reservoirs of infection, primarily due to the material they are made of (glass, plastic and metal). This is also confirmed by the research given in the appendix in Table 2, where it has been proven that SARS Cov 2 (Covid 19) lives the longest on plastic and stainless steel.

Table 2 Sars Cov 2(Covid 19) lifespan on different materials [ 20] [ 21]

\begin{tabular}{|l|l|}
\hline Material & Sars Cov 2(Covid 19) lifespan on different materials \\
\hline \multirow{2}{*}{ Glass } & $\begin{array}{l}\text { Measurements of } 0-3 \mathrm{~h}, \mathrm{~T} 1 / 2=1.3 \mathrm{~h} \\
3 \mathrm{~h}-2 \text { days, T1/2 }=4.8 \mathrm{hrs}\end{array}$ \\
\hline \multirow{3}{*}{ Banknote } & $\begin{array}{l}\text { Measurements of } \\
0-6 \mathrm{~h}, \mathrm{~T} 1 / 2=0.9 \mathrm{~h} \\
6 \mathrm{~h}-2 \text { days, T1/2=7.9 h }\end{array}$ \\
\hline Stainless steel & $\begin{array}{l}0-30 \mathrm{~min}, \mathrm{~T} 1 / 2=0.3 \mathrm{~h} \\
30 \mathrm{~min}-4 \text { days, } \mathrm{T} 1 / 2=14.7 \mathrm{~h}\end{array}$ \\
\hline \multirow{2}{*}{ Plastic } & $\begin{array}{l}0-6 \mathrm{~h}, \mathrm{~T} 1 / 2=1.6 \mathrm{~h} \\
6 \mathrm{~h}-4 \text { days, T1/2=11.4 hrs) }\end{array}$ \\
\hline \multirow{2}{*}{ Paper } & $0-30 \mathrm{~min}=4.76 \mathrm{~h}$ \\
& $30 \mathrm{~min}-2$ days $=1.18 \mathrm{~h}$ \\
\hline
\end{tabular}

Out of respondents who have an open mobile application, which mainly refers to the very young population aged $18-25$, and recently the more mature population aged 35 to 45 and over, only $1 / 3$ of the respondents mainly use it to pay for utilities, electricity, water, telephone and other charges.

The dominant way of withdrawing cash by the respondents is from ATMs, while more than $1 / 3$ of respondents decide to withdraw cash directly from the counters at the post office and savings bank, as it is a case with: salaries, pensions, various social benefits, payments for other person's care, social assistance and other forms social benefits.

If we analyze Table 3 in the package of financial services of the Postal Savings Bank of the Kosovska Mitrovica Branch Office, which are the unofficial information gathered by the authors of the paper through interviews with employees of the BankPostal Savings Bank, the incrase of contactless payment method has been observed, as opposed to the period before the pandemic. In order to support this claim, the evident growth of $\mathrm{e}+\mathrm{m}$ and home electronic services through the so-called mobile wallets of the bank-postal savings bank can be used On the other hand, the number of counters of the Postal Savings Bank branch office in Kosovska Mitrovica for cash withdrawals does not support the affirmation of the contactless method of payment, because it has remained the same before and during the COVID 19 pandemic.

When using the financial services and payment methods, this research recorded a small number of POS terminals, e.g., many small shops that are the dominant type of retail, in the north of Kosovo and Metohija, do not have the POS terminals. 
In proportion to these technical limitations, we note elements of insufficient or very low financial literacy of bank/postal savings bank clients regarding the scope and practical application of electronic services using mobile applications. Political and security troubles in the north of Kosovo and Metohija also contribute to this state of modest and timid affirmation and spreading of contactless payment methods.

A certain compensation should be mentioned here - a financial reason for not or insufficiently using POS terminals, both from the point of view of the bank's clients /bank users/ postal savings bank, which limits this payment method in a certain way.
In order to distance the client from the counter cash withdrawal method Bank in favor of contactless payment, the management of the Postal Savings, the abovementioned financial institution raised the limit for ATMs cash withdraw from 20,000 dinars to 50,000 dinars and thus encouraged this model of financial services during the COVID pandemic.

For this purpose of deterrence from the cash method of payment, we have a certain percentage of commission for withdrawing cash from the counters and ATMs, if you are not a bank client, i.e. you do not have a bank savings bank card. Data related to internet payment were not available to us while the so-called code telephone payment at this branch in Serbia is still in its infancy.

Table 3 Financial services package of the Postal Savings Bank of the Kosovska Mitrovica branch office*

\begin{tabular}{|c|c|c|c|c|}
\hline $\begin{array}{l}\text { Type of service / branch } \\
\text { office } \\
\text { Kind of financial services- } \\
\text { payment method / branch } \\
\text { office }\end{array}$ & $\begin{array}{l}\text { Branch office } \\
\text { K. Mitrovica-total } \\
\text { Before during } \\
\quad \text { pandemic }\end{array}$ & $\begin{array}{l}\text { Zvečan } \\
\text { Before during } \\
\text { pandemic }\end{array}$ & $\begin{array}{l}\text { Z. Potok } \\
\text { Before during } \\
\text { pandemic }\end{array}$ & $\begin{array}{l}\text { Leposavić } \\
\text { Before during } \\
\text { pandemic }\end{array}$ \\
\hline Number of counters & 5 & 2 & 2 & 2 \\
\hline Number of ATMs & 5 & 2 & 1 & 1 \\
\hline Number of cards & $22,00036,000$ & $4,500 \quad 7,000$ & $1,000 \quad 1,500$ & $2,500 \quad 3,300$ \\
\hline Number of POS terminals & $\begin{array}{l}41 \text { out of which } \\
\text { K. Mitrovica } \\
31 \text { Before and } \\
\text { during pandemic }\end{array}$ & 5 & 3 & 2 \\
\hline $\begin{array}{l}\text { e bank services for legal } \\
\text { entities-number e transaction }\end{array}$ & $2,400 \quad 9,600$ & $700 \quad 3,800$ & $1,200 \quad 6,400$ & 1,700 \\
\hline $\begin{array}{l}\mathrm{m} \text { bank services }+ \text { home ser- } \\
\text { vices for individuals-number of } \\
\mathrm{m} \text { and } \mathrm{h} \text { transactions }\end{array}$ & $600 \quad 3,000$ & $400 \quad 2,100$ & 2,600 & 1,900 \\
\hline $\begin{array}{l}\text { Internet payment } \\
\text { - purpose defined visa } \\
\text {-master card } \\
\text {-electron visa }\end{array}$ & No data & No data & No data & No data \\
\hline $\begin{array}{l}\text { QR payment-so-called tele- } \\
\text { phone. code payment }\end{array}$ & It is still dev & CI & ovo and Met & and in Serbia \\
\hline
\end{tabular}

* Note: The financial services package refers to the period shortly before the pandemic of March 2020 to December 2020.

Source: Author's overview based on data collected through interviews and on information from the Postal Savings Bank of the Kosovska Mitrovica Branch Office 


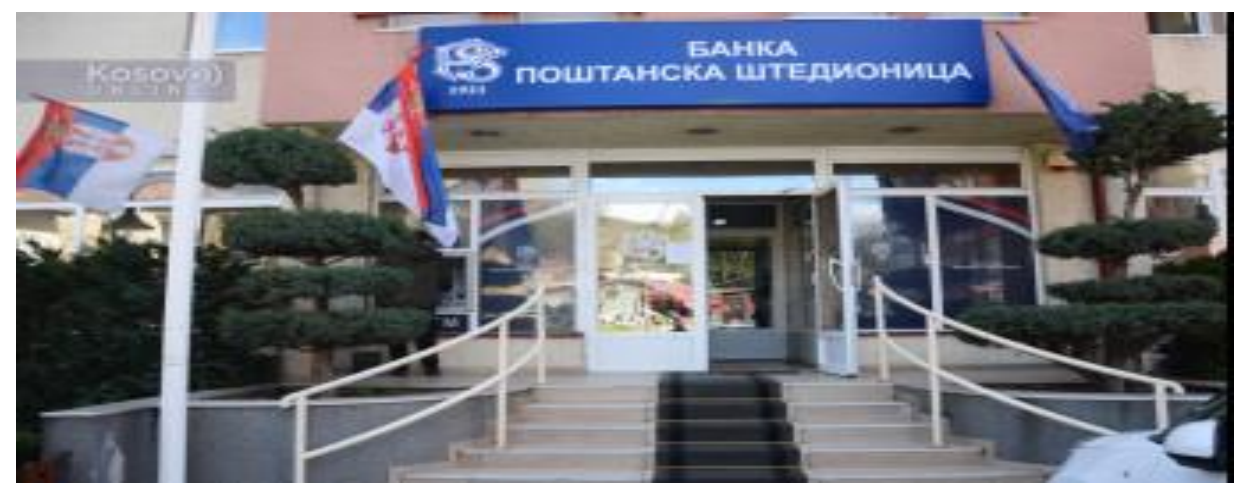

Figure 5 Postal Savings Bank of the Kosovska Mitrovica

\section{CONCLUSION}

From the point of writing a paper on contactless payment via cards, mobile wallets and other models of electronic payments, the need for cash has been forgotten. We have proven that by the use of contactless payment, you pay from a secured, and especially healthly safe distance, along with what the contactless method of payment provides the most: speed, security, simplicity and convenience from any location. Research conducted in the first two studies has shown that the toxicity and transmissibility of SARS Cov 2 or COVID 19 in the use of cash and paper money is great, but there are also the other materials from which ATM and POS terminals are made of, primarily due to metal, glass and plastic. It has been proven that, primarily due to these circumstances, mobile applications as a payment model are the most secure and thus the safest method for the health aspect and the most practical from anywhere. Contactless payment is today, in time of the pandemic, the main style in all the economies of the world and Europe, which can be regarded as leaders, but there are exceptions. After all, COVID 19 only accelerated the "death" of the cash method of payment in the developed Europe with the components of the so- called commodity variety of payment methods, especially in the so-called countries of the new Europe, Bulgaria and Romania. The contactless payment model is still in its infancy, but also in development in the Balkans region and Serbia. People pay more often by a card in Luxembourg and France. The Scandinavian countries are at the very top of the scale. There, many hotels, bars or shops do not want to accept payment with coins and banknotes at all. In Sweden, $82 \%$ of people pay non-cash. We have shown in the paper that the greatest opportunity for contactless payment will be in the future in markets such as Southeast Asia and Latin America, where cash consumption dominated in the previous period. China, through the form of contactless payment methods, has been dominating on a global level for many years, and with the pandemic, it has only confirmed its first place in the world in that respect. Finally, it is evident that the growth of e-commerce and payments is expanding, even more so during the COVID 19 pandemic. A practical live study in form of a survey and field interviews about the diversity/limitations of various modalities of financial services of the Postal Savings Bank of Kosovska Mitrovica, only showed a 
growing trend of contactless payment method versus cash payment, with all the weaknesses and limitations that accompany the development of various payment methods at this branch office. From a health point of view, this means that a trend or choice of a safer payment model is growing, but that is still in its infancy. This only leaves a question for some further research on that topic in perspective.

\section{REFERENCES}

[1] Khalek Y.A., and Bakri A. (November 2017): The E Banking in Emerging Markets, International Journal of Development Research, Vol 07, Issue 11, pp.17186-17192, downloaded: https://www.journalijdr.com/sites/ default/files/issue-pdf/11192.pdf Date of access: $20 / 05 / 2020$

[2] Sundarraj R.P and Wu J. (2005), "Using Information - Systems Constructs to Study Online - and Telephone-Banking Technologies", Electronic Commerce Research and Applications, Vol.4 No.4, pp.427-443.

[3] Daniel, E. (1999), "Provision of Electronic Banking in the UK and the Republic of Ireland", International Journal of Bank Marketing, Vol.17 No.2, pp.72-82.

[4] Mols N.P. (2001), "Organizing for the Effective Introduction of New Distribution Channels in Retail Banking”, European Journal of Marketing, Vol.35 No.5-6, pp.661-686.

[5] Dootson, P., Beatson A. and Drennan, J. (february 2016), "Financial Institutions Using Social Media - Do Consumers Perceive Value?", International Journal of Bank Marketing, Vol. 34 No.1, Emerald publishing, pp.9-36
[6] Ilić, N. M., Spalević, Ž. and Veinović, Mladen. (november 2015). E Banking Application and Security, Conference: Sinergija, in Bijeljina, Bjeljina, Vol. 16 No. 1, pp.113 downloaded:

https://www.researchgate.net/ publication/289525272_Elektronsko_b ankarstvo_-Primena_i_Sigurnost, Date of access: 20/08/2020

[7] Samonagesh, V., Ganesh, S., M. Sathish, M. T. (Avgust-October 2020). Impact of Covid-19 Outbreak in Digital Payments, International Journal for Innovative Research in Multidisciplinary Feld, Volume 6, Issue 8, pp.159 downloaded: (PDF) Impact of Covid-19 Outbreak in Digital Payments (researchgate.net) Date of access: 24/08/2020

[8] https://www.cnbc.com/select/ mastercard-survey-contactlesspayments/

[9] https://newsroom.ucla.edu/releases/ covid-19-through-air-contaminatedobjects Date of access: 05/06/2020

[10] Doremalen, V. N., Bushmaker, T., Morris, H. D., Holbrook, G. M., Gamble, A., Williamson, N. B. (March 2017, 2020). Aerosol and Surface Stability of SARS-CoV-2 as Compared with SARS-CoV-The New England Journal of Medicine downloaded:

https://www.nejm.org/doi/pdf/10.1056/ NEJMc2004973, Date of access: 24/04/2020

[11] https://www.newindianexpress.com /states/kerala/2020/mar/22/atms-posmachines-remain-hotspots-of-virustransmission-2120098.html, (Date of access: 10/08/2020)

[12] https://www.wunc.org/post/newcoronavirus-can-live-surfaces-2-3days-heres-how-clean-them (Date of access: 05/04/2020) 
[13] G. Kampf, D. Todt, S. Pfaender, E. Steinmann, (February 6, 2020) "Persistence of Coronaviruses on Inanimate Surfaces and Their Inactivation with Biocidal Agents", Journal of Hospital Infection, Vol. 104, Issue 3, pp. 246251. DOI: https://doi.org/10.1016/j. jhin.2020.01.022

[14] https://www.businesswire.com/ news/home/20201124005256/en/COV ID-19-Increases-Urgency-for-Banksto-Transform-Payment-Systems-asDigital-Payments-Soar-FindsResearch-from-Accenture (Date of access: 10/12/2020)

[15] https://www.thalesgroup.com/en/ markets/digital-identity-and-security/ banking-payment/cards/contactless (Date of access: 10/11/2020)

[16] https://www.emarketer.com/content/ global-mobile-payment-users-2019 (Date of access: 05/03/2020)

[17] https://www.emarketer.com/chart/ 240924/proximity-mobile-paymentusers-western-europe-2019-2023millions-change (Date of access: 01/01/2021)

[18] https://thepaypers.com/mobilepayments/mobile-wallet-payments-tosurge-by-50-percent-in-2020--1242730 (Date of access: 05/09/2020)

[19] Annoor Awadasseid1, Yanling Wu, Yoshimasa Tanaka Wen ZhangInitial, Intial Success in the Identification and
Management of the Coronavirus Disease 2019 (COVID-19) Indicateshuman - to - Human Transmission in Wuhan, China, International Yournal of Biological Sciences, 2020; 16(11), Reviev, IVYSPRING, International publisher, doi: 10.7150/ ijbs.45018 pp. 1856 https://www.ijbs.com/v16p1846.pdf, (Date of access: 05.06.2020.).

[20] Chin, A. W H., Chu, J. T. S., Perera, M. R.A. et al. Stability of SARS-CoV2 in Different Environmental Conditions. Lancet Microbe, Volume1, Issue 1, (May 2020); published online April 2, pp.411 https://doi.org/10.1016/S2666-5247 (20)30003-3 (Date of access: $10 / 07 / 2020)$

[21] https://www.thelancet.com/cms/10. 1016/S2666-5247(20)30003-3/ attachment/bfda5654-ca06-42d3-8beb$5 \mathrm{f} 3 \mathrm{aa} 5 \mathrm{fc} 2 \mathrm{df0} / \mathrm{mmc} 1 . \mathrm{pdf}$ Date of access:11/05/2020, pp. 1-8

[22] https://www.dnb.nl/en/news/news-andarchive/dnbulletin2020/dnb391390.jsp

[23] V. Radovanović, Lj. Savić, Knowledge and Innovations -Key Factors of Development and Emloyment in the Mining Companies, Mining and Metallurgy, N1, 2014, Institute Bor, https://irmbor.co.rs/wp-content/ uploads/2016/12/mmebor1_14.pdf, pp. 154 